\title{
THE STIMULI OF THERMAL ENVIRONMENT DEFINED ACCORDING TO UTCI IN POLAND
}

\section{Magdalena Kuchcik ${ }^{1}$ (D) Krzysztof Błażejczyk ${ }^{2}$ (D) Agnieszka Halaśs ${ }^{3}$}

${ }^{1,2}$ Climate Impacts Laboratory, Institute of Geography and Spatial Organization

Polish Academy of Sciences

Twarda 51/55, 00-818 Warsaw: Poland

e-mails: mkuchcik@twarda.pan.pl ${ }^{1}$ (corresponding author)・kblaz@twarda.pan.pl ${ }^{2}$

3 Past Landscape Dynamic Laboratory, Institute of Geography and Spatial Organization

Polish Academy of Sciences

Twarda 51/55, 00-818 Warsaw: Poland

e-mail: aj.halas@twarda.pan.pl

\begin{abstract}
The assessment of thermal stress stimuli in Poland was based on the Universal Thermal Climate Index (UTCI). Daily values of UTCI at 24 stations selected to represent the whole area of Poland at 12:00 UTC were calculated over the period 1951-2018. Various UTCI characteristics, i.e., spatial averages of daily, monthly and annual values, daily spatial contrasts (i.e., the difference between daily highest and lowest UTCI values) were defined in each of 8 bioclimatic regions of Poland. Ten-year trends for UTCI and spatial contrast values were counted and their statistical significance was analysed. A statistically significant increase in UTCl values was found in all the regions of Poland. However, contrasts in thermal stress both for Poland as a whole and in most of the regions decreased significantly, especially in the north-east of Poland, the country's coldest region. This indicates a reduction in the stimuli of thermal environment in Poland and in most of the individual regions.
\end{abstract}

\section{Key words}

thermal stress - climate change $\cdot$ long series data $\cdot$ regionalization $\cdot$ spatial contrasts - Universal Thermal Climate Index

\section{Introduction}

The human organism is constantly affected by stimuli from all of the atmospheric environment, comprising both the basic meteorological elements (solar radiation, air temperature and humidity, atmospheric pressure, air movement, and precipitation), and air composition (gaseous and particulate), its ionisation, intensity of electromagnetic fields, noise, vibration, smell, as well as living organisms in the air (aeroplankton) (WMO, 1999). These elements are customarily classed into three groups: physical, biological and chemical stimuli. 
One of the main ways in which the human body senses the external environment is thermal sensation or thermal stress (whatever name it takes and in whatever manner, simple or more complex, it is calculated). The socalled "thermal environment" comprises both atmospheric heat exchange conditions (stress) and the physiological response (strain) (Jendritzky et al., 2012). It depends not only on air temperature, but also on the intensity of solar radiation, air humidity and wind speed (Köppe et al., 2004; Gasparini et al., 2015). The human autonomous thermoregulatory system reacts to ambient stimuli in many ways depending on ambient temperature (low or high), and attempts to balance the heat budget and to maintain the thermal equilibrium of the body core (Kenney, 1985; Parsons, 2014; Cheshire, 2016). These biological processes are supported by behavioural adaptation.

In bioclimatic research several indicators of heat exposure that consider the physical properties of the ambient environment have been developed (Epstein \& Moran, 2006; Błażejczyk et al., 2012; Parsons, 2014; de Freitas \& Grigorieva, 2017). Among them the Universal Thermal Climate Index (UTCI), which defines thermal stress in humans, has been applied more and more frequently in bioclimatic research. UTCl is used for instance in research on mortality and morbidity (Nastos \& Matzarakis, 2012; Urban and Kyselý, 2014; Burkart et al., 2016; Kuchcik, 2017, 2020; Błażejczyk et al., 2018), work effectiveness (Bröde et al., 2013), assessment of bioclimatic potential for tourism and recreation (Błażejczyk \& Kunert, 2011), evaluation of urban bioclimate (Błażejczyk et al., 2014; Cheung \& Hart, 2014) and many other areas.

Climate changes, observed worldwide and which have accelerated after 1990. (e.g. IPCC, 2013, 2018; Heim, 2015; National Academies of Sciences, Engineering, and Medicine, 2016; Lewis \& King, 2017) cause changes in bioclimatic conditions what reflects also in Polish studies (e.g. Piotrowicz, 2007; Wibig et al. 2009a, b; Błażejczyk \& Twardosz, 2010; Kuchcik, 2017). However, as bioclimatic indicators require the input of a wide range of meteorological data and their preparation and calculation is timeconsuming, they are not frequently analysed. So far only few studies have presented long-term historical changes in UTCl and many of them concern Poland (Okoniewska \& Więcław, 2013; Błażejczyk et al., 2015; Kuchcik, 2017; Owczarek, 2019; Wu et al., 2019; Dobek et al., 2020; Tomczyk \& Owczarek 2020; Zeng et al., 2020). Lastly, di Napoli et al. (2020) have developed UTCI time series as a sequence of spatial grids at $0.25^{\circ}$ resolution (approximately $31 \mathrm{~km}$ at the equator) and 1 hour intervals for the period 1981-2019.

Thermal stress changes both over time and spatially. As well as changing daily, seasonally and multiannually, perceived conditions also vary depending on location. This is why in addition to general regionalizations of Poland's climate (Romer, 1949; Okołowicz \& Martyn, 1979; Woś, 1993), climate and agricultural (Gumiński, 1948), and pluviothermal regionalizations (Schmuck, 1965; Ziernicka-Wojtaszek \& Zawora, 2008), also regionalizations based on the structure of active surface heat balance (Paszyński \& Krawczyk, 1970) and values of biometeorological indicators (Kozłowska-Szczęsna, 1991; Krawczyk, 1993; Błażejczyk, 2004) have been elaborated. The latter two took into account climate stimuli, that is the variability over time of climate feature values.

The current paper attempts to assess both $\mathrm{UTCl}$ values themselves in areas (regions) with differing bioclimatic features, and maximum daily differences in UTCl between stations in a given region, as well as their changes over the period 1951-2018. The purpose of the paper is a general analysis of the stimuli of bioclimatic conditions, understood mainly as the extreme daily UTCI values but also as their contrasts in the region. The multiannual variability of spatial contrasts and their trends are also under analysis.

\section{Data}

In the study daily values of UTCI at 12:00 UTC (respectively $1 \mathrm{pm}$ winter time, $2 \mathrm{pm}$ summer time) were calculated. The analysed 
period covers 68 years, from 1951 to 2018, and data were collected at 24 stations selected to represent the whole area of Poland (Fig. 1). In three stations, measurement started slightly later: on 19.11 .1952 in Mikołajki, on 17.06.1954 in Lesko and on 1.01.1955 in Terespol. In Mikołajki there was one, almost 2-year, break in data lasted from 1.05.1992 to 31.12.1993. Except for this gap, the remaining data was $99.3-100 \%$ complete. Also as a result of lack of data in Lesko in the Carpathian region, in which only 2 stations have been taken into account, differences between UTCI values in Zakopane and Lesko were analysed from 1955.

The meteorological stations used in this research were assigned to areas approximately reflecting bioclimatic regions (KozłowskaSzczęsna et al., 2002; Błażejczyk \& Kunert, 2011) and their specific patterns of geographical environment: Coastal (A, influenced by the Baltic Sea), Lakeland (B, lake district in the north of Poland, transitional between
Coastal and Central), North-eastern (C, exposed to advection of arctic and continental air masses, the coldest), Central ( $D$, the biggest, containing mainly lowlands, which are strongly influenced by traversing of oceanic and continental air masses), Eastern ( $E$, with increased advection of polar continental air), Sudetic ( $F$, where vertical changes of meteorological parameters contribute to the climate and bioclimate of the area but which is more influenced by oceanic air masses than the Carpathians) and Carpathian ( $G$, more influenced by continental air masses) and Mountain summits $(H$, with the most stimuli and severe weather). These areas differ from the bioclimatic regions as used in previous works because on the basis of previous UTCI studies and with only 24 stations, the authors decided to include Tarnów in the central region. Moreover, mountain summits (Śnieżka and Kasprowy Wierch) were removed from the mountainous regions and grouped as a distinct region. This is why authors used letters not the Roman

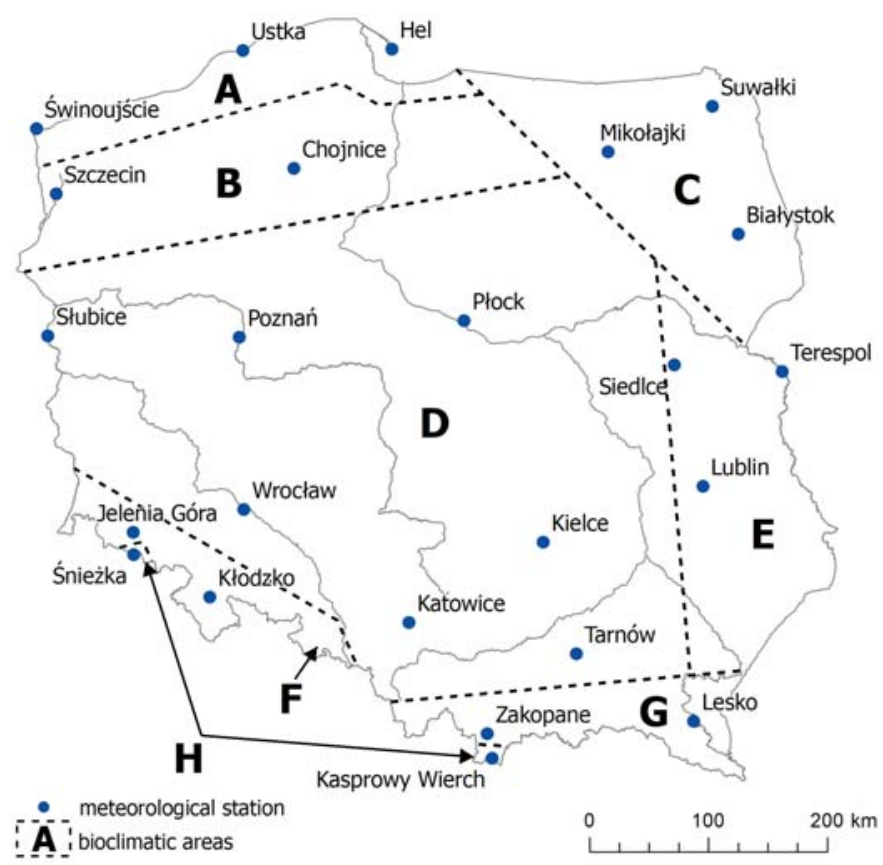

Figure 1. Distribution of stations used in the study and approximate dividing lines of the areas to which stations were assigned; symbols explained in the text 
numbers to underline that areas differ from Polish bioclimatic regions and not confuse them (Błażejczyk, 2004). Also the lines separating the areas in Figure 1 are indicative only and are not the borders between bioclimatic regions, they are approximate lines dividing group of the stations one from another. In the paper the Authors will use the terms regions and areas interchangeably (Fig. 1).

\section{Methods}

To assess the changes in thermal stress conditions in Poland the Universal Thermal Climate Index (UTCl, Błażejczyk et al., 2012; Bröde et al., 2012) was used. UTCl reflects the intensity of heat and cold stress in humans, which are physiological reactions of an organism to atmospheric stimuli. UTCl is defined as the ambient temperature of the reference condition causing the same model response as the actual condition. Thus, UTCI is an equivalent of air temperature which would produce, under reference conditions, the same thermal strain as in the actual thermal environment. The deviation of UTCI from air temperature depends on the actual values of air temperature $(\mathrm{Ta})$, mean radiant temperature (Tmrt calculated on the basis of cloud cover), wind speed (va - assuming that the smallest wind speed on $10 \mathrm{~m}$ was $0.5 \mathrm{~m} \cdot \mathrm{s}^{-1}$ and the highest was $27 \mathrm{~m} \cdot \mathrm{s}^{-1}$, the range of wind speed values UTCI was mainly created for) and humidity, expressed as water vapour pressure (vp) or relative humidity $(\mathrm{RH})$.
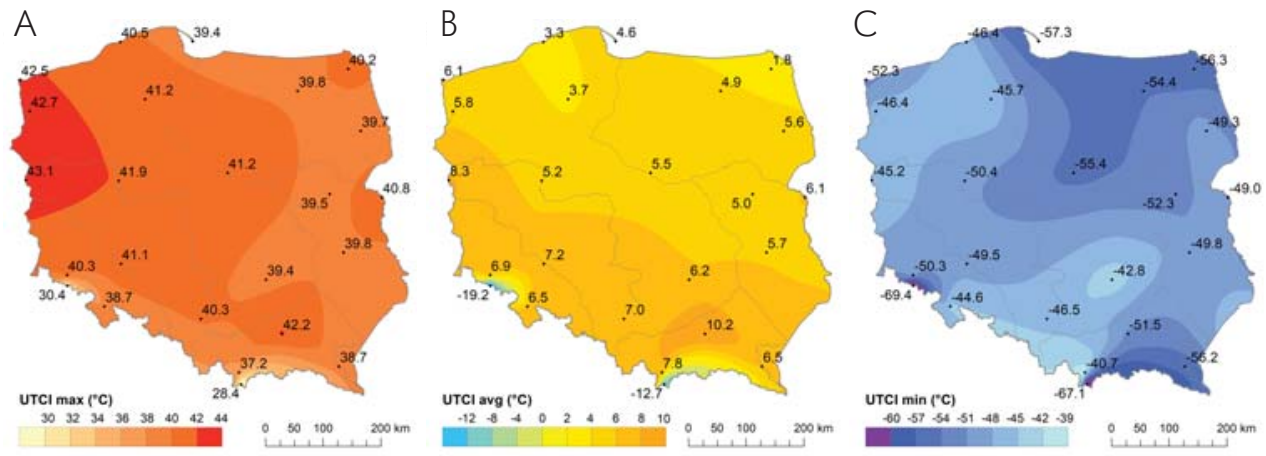

Figure 2. The highest (A), yearly average (B), and lowest (C) UTCl values at 12:00 UTC, 1951-2018
To start with, of the UTCl values from 12:00 UTC in all stations of the given area were calculated. Then daily lowest (UTCImin) and highest (UTCImax) values at all the stations in the area were indicated and the spatial average (UTClavg) were calculated (e.g. UTCImin is the lowest UTCl value in given day among 3 stations in sea area, UTCImax - the highest, and UTClavg - the spatial average of the values from all 3 stations representing sea area). In the next step, spatial averages of daily, monthly and annual UTCI values within all the considered areas were examined similarly as in Błażejczyk et al. (2015) research.

Next, daily UTCI spatial contrasts (dUTCI) in each of the areas, defined as the difference between the daily highest and lowest UTCI values in given area, were analysed. Based on dUTCl, monthly and yearly means (dUTClavg) were calculated. The highest (dUTCImax) and lowest (dUTCImin) contrast values for individual months and the whole year were also established. Ten-year moving averages and 10-year trends of dUTClavg, dUTCImax and dUTCImin were calculated and their statistical significance was verified with Stragraphics Centurion XVI, version 16.2.04. UTCI was calculated using the BioKlima 2.6 software package.

The distribution of UTCI values presented on the maps (Fig. 2) were drawn using ESRI ${ }^{\circledR}$ ArcMap 10.6.1 software. The spatial distribution of UTCImax, UTClavg and UTCImin in Poland was based on data from 24 stations 
using the Natural Neighbor Interpolation method (Spatial Analyst Toolbox). This method was selected because it is the most appropriate for continuous variables (e.g. temperature) with uneven distribution of data points. The obtained results were then extrapolated to the Polish borders.

\section{Results}

\section{General characteristic of UTCI in Poland}

Thermal stress conditions in Poland are spatially differentiated. Individual UTCI characteristics (maximum, minimum and mean values) vary by region. The highest UTClavg values $\left(10.2^{\circ} \mathrm{C}\right)$ were noted in the south in the Sandomierski Basin (Tarnów). The spatial distribution of yearly UTClavg follows diagonal belts running from the north-west to the south-east: the lowest values were recorded in the north-east and the highest ones, in the south and south-west, except in mountainous areas (Fig. 2). The highest values for UTCImax $\left(>40^{\circ} \mathrm{C}\right)$ were noted in western and central Poland and the lowest ones, in mountainous regions, especially on summits. The opposite distribution occurred for UTCImin. In this case, the lowest values $\left(<-40^{\circ} \mathrm{C}\right.$, but sometimes reaching values even below $-55^{\circ} \mathrm{C}$ ) were observed in north-eastern and mountain regions (especially the Carpathians). Relatively high UTCImin values were noted in northwestern Poland and in the central upland region (Kielce, Katowice). One of the reasons for such a distribution is that north-eastern and eastern Poland is influenced by frequent advections of arctic and polar continental air masses, but in western and north-western areas increased frequency of oceanic air masses is visible (Fig. 2).

In turn, in the years 1951-2018 the spatial UTCl average from all 24 stations was $5.9^{\circ} \mathrm{C}$, the average annual minimum UTCl was $-25.7^{\circ} \mathrm{C}$, and average annual maximum UTCl, $32.6^{\circ} \mathrm{C}$ (Tab. 1). In a spatial analysis of average UTCl values in regions excluding mountain summits, the North-eastern area was the coldest with an average $\mathrm{UTCl}$ of $4.1^{\circ} \mathrm{C}$, while the Carpathian region with an average UTCI of $7.2^{\circ} \mathrm{C}$ and the Central region $\left(7.1^{\circ} \mathrm{C}\right)$ were the warmest; however, in the Central region the average minimums and maximums were higher. The highest spatial averages in almost all the regions except the Carpathians and mountain summits were above $38^{\circ} \mathrm{C}$, which indicates very strong heat stress. The lowest, in turn, were more differentiated and varied from under $-50^{\circ} \mathrm{C}$ in the Coastal and Eastern regions (A, C, $E)$, which indicates extreme cold stress, to ca. $-40^{\circ} \mathrm{C}$ in the Central and Carpathian regions. Mountain summits were characterized by completely different conditions. The Sudetic region was colder than the Carpathian one in terms of UTCl, mostly because minimum values were considerably lower than in the Carpathians; however, maximum values were higher than in the Carpathian region (Tab. 1).

Table 1. Spatial averaged $\mathrm{UTCl}\left({ }^{\circ} \mathrm{C}\right.$ ) values (avg); average annual and absolute values of minimum (min) and maximum (max) UTCl in individual areas

\begin{tabular}{|l|c|c|c|c|c|c|c|}
\hline \multicolumn{1}{|c|}{ Areas } & Avg & Min & Max & Min abs & Date & Max abs & Date \\
\hline PL- Poland & 5.9 & -25.7 & 32.6 & -39.6 & 31.12 .1978 & 37.8 & 10.08 .1992 \\
A - Coastal & 4.7 & -29.4 & 32.1 & -51.2 & 31.12 .1978 & 38.3 & 10.08 .1992 \\
B - Lakeland & 4.7 & -30.6 & 33.9 & -44.6 & 31.12 .1978 & 40.3 & 10.08 .1992 \\
C - North-eastern & 4.1 & -34.3 & 33.4 & -50.7 & 31.12 .1978 & 39.0 & 31.07 .1994 \\
D - Central & 7.1 & -26.5 & 34.8 & -39.5 & 15.01 .1963 & 39.5 & 12.07 .1959 \\
E - Eastern & 5.6 & -32.4 & 34.9 & -50.4 & 31.12 .1978 & 39.3 & 12.07 .1959 \\
F - Sudetic & 6.7 & -28.1 & 34.5 & -45.0 & 17.01 .1955 & 39.5 & 27.07 .1983 \\
G - Carpathian & 7.2 & -27.2 & 32.7 & -40.7 & 07.01 .1982 & 37.0 & 11.08 .2017 \\
H - Summits & -16.0 & -56.1 & 21.7 & -63.6 & 13.01 .1968 & 27.4 & 04.07 .1952 \\
\hline
\end{tabular}


One of the coldest days in Poland, especially in regions $A, B, C, E$ and the north half of region $D$, was 31 December 1978 . On that day UTCl at $12: 00$ UTC reached $-57.3^{\circ} \mathrm{C}$ in $\mathrm{Hel}$ (region) and was below $-50^{\circ} \mathrm{C}$ in many cities. That day the spatial averages of UTCI reached their absolute minimums in the whole north and north-east Poland (A, B, C, E areas) as well and in the whole area of Poland (Tab. 1).

The warmest day in terms of thermal stress in Poland was 10 August 1992, when under clear skies and with almost no wind air temperature in Słubice on the west polish border rose to $37.3^{\circ} \mathrm{C}$ and $\mathrm{UTCl}$ up to $43.1^{\circ} \mathrm{C}$, with values in Szczecin just slightly lower (Fig. 2). That day the maximum spatial UTCI averages for whole Poland and in Coastal and Lake district were noted (Tab. 1).

\section{Time changes of spatially averaged UTCI}

During the whole period, UTCI values rose, but minimum values rose more steeply than maximum values. The average increase in $\mathrm{UTCl}$ in Poland was $0.44^{\circ} \mathrm{C} / 10$ years, from $4.4^{\circ} \mathrm{C}$ in 1951 to $7.4^{\circ} \mathrm{C}$ in 2018 . The largest increase in UTCI was recorded in the Northeast $(\mathrm{C})$, where it reached $0.73^{\circ} \mathrm{C} / 10$ years on average. The lowest was in the Sudetes, but it was statistically significant at $p \leq 0.05$ in all regions. UTCImin values rose far more rapidly than averages, reaching $1.70^{\circ} \mathrm{C} / 10$ years in the North-east and around $1.0^{\circ} \mathrm{C} / 10$ years in the Central and in mountainous regions. The increase was statistically significant everywhere apart from the Coastal region. The growth of UTCImax was the lowest, varying from $0.18^{\circ} \mathrm{C} / 10$ years in the Sudetes and on the coast to $0.42^{\circ} \mathrm{C} / 10$ years in the northeast, and was $0.28^{\circ} \mathrm{C} / 10$ years on average in Poland, and statistically significant (Tab. 2).

The different nature of thermal stimuli in the Sudetes and Carpathians is well seen. The increase in UTCl in the Carpathians was higher than in the Sudetes: this particularly refers to UTCImax, whose growth was twice as high.
Table 2. Ten-year trends for yearly UTClavg, UTCImin and UTCImax $\left({ }^{\circ} \mathrm{C}\right)$ spatially averaged for Poland and for individual areas 1951-2018 (the bolded values are statistically significant at $p \leq 0.05$ )

\begin{tabular}{|l|c|c|c|}
\hline \multicolumn{1}{|c|}{ Area } & Avg & Min & Max \\
\hline PL- Poland & 0.44 & 0.75 & 0.28 \\
A - Coastal & 0.46 & 0.65 & 0.18 \\
B - Lakeland & 0.37 & 0.74 & 0.20 \\
C - North-eastern & 0.73 & 1.70 & 0.42 \\
D - Central & 0.44 & 0.98 & 0.26 \\
E - Eastern & 0.39 & 0.93 & 0.27 \\
F - Sudetic & 0.25 & 1.01 & 0.18 \\
G - Carpathian & 0.42 & 1.06 & 0.37 \\
H - Summits & 0.27 & 0.63 & 0.24 \\
\hline
\end{tabular}

A chart of the UTCl profile over the 68 consecutive years shows that UTCImin was characterised by the highest year-to-year variability. In 1978 UTCImin was $-39.6^{\circ} \mathrm{C}$, while 3 years before, in 1975 , only $-18.5^{\circ} \mathrm{C}$. Similarly in 1987 it was $-36.9^{\circ} \mathrm{C}$, but 3 years later in $1990,-16.8^{\circ} \mathrm{C}$. UTClavg growth was more stable, although the period between the years mentioned above, 1975 and 1990, saw the greatest fluctuations. The growth of UTCImax was the smallest, but there are two distinct periods in its course: lower values were recorded in the years 1975-1987, with years with very high UTCImax values, 1989, 1992 and 1994, occurring right after them (Fig. 3).

\section{Spatial contrasts in UTCl within bioclimatic areas and within whole Poland}

The paper presents not only UTCl values in the designated areas, but most importantly the spatial contrast in UTCI in a given area (dUTCl) at 12:00 UTC. Furthermore, it shows contrasts in UTCl for Poland as a whole, excluding mountain summits as with them the differences would be almost twice as high. Obviously, in smaller regions, which are thus less diverse in terms of weather, the contrasts were lower than for Poland as a whole. The average daily spatial contrast (dUTClavg) 
for Poland in the years $1951-2018$ was $21.1^{\circ} \mathrm{C}$ $\left(38.7^{\circ} \mathrm{C}\right.$ including summits), the average of the lowest contrasts (dUTCImin) was $7.5^{\circ} \mathrm{C}$,
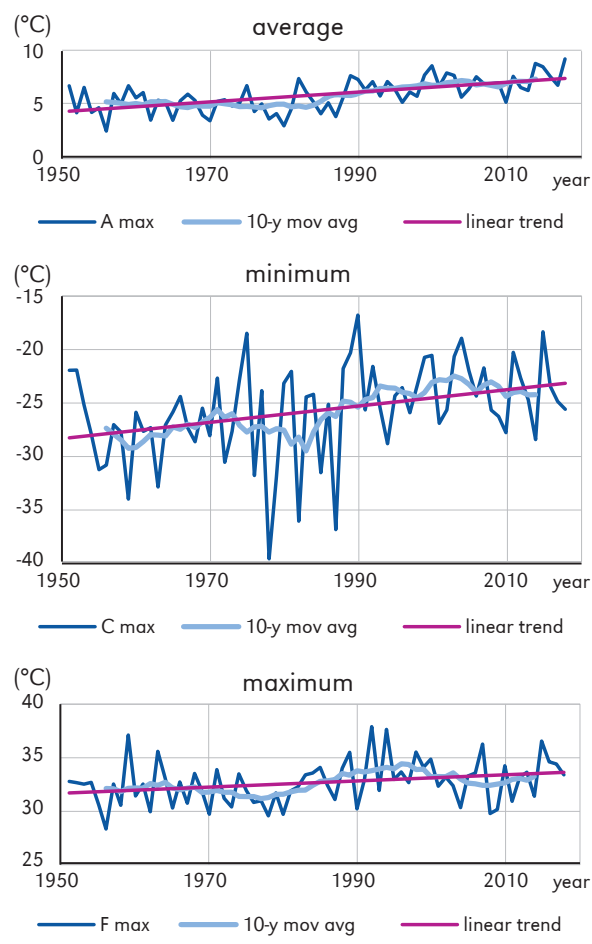

Figure 3. Multiannual changes in spatially averaged yearly values of UTClavg, UTCImin and UTCImax for Poland with trend and 10-year moving averages (10-y mov avg), 1951-2018 and of the highest contrasts (dUTCImax), $45.6^{\circ} \mathrm{C}$ (Tab. 3).

The lowest variability in UTCl was present in the central region (D), where average contrasts in dUTClavg were $13.4^{\circ} \mathrm{C}$, and the lowest difference between individual stations was $2.7^{\circ} \mathrm{C}$. In most regions the smallest spatial contrasts approached 0 , which means that on a given day at 12:00 UTC, these stations had the same thermal stress conditions. This was the case even for mountain summits $(H)$, where, in turn, the highest dUTClavg were noted, with an average of $48.8^{\circ} \mathrm{C}$. The smallest variation in UTCl was observed for the Lakeland region (B). In fact only 2 stations represent the region, although they are located at a distance of $200 \mathrm{~km}$ and UTCl characteristics indicate that they are quite similar according to weather. The Northeastern area is also climatically consistent, though it is representing also by 2 stations, located $100 \mathrm{~km}$ apart (Tab. 3).

In the 68 years analysed, the greatest differences in UTCl in Poland and in individual regions occurred in the first half of the analysed period, and in most regions, in the 1950s and 1960s. However, the greatest contrasts in UTCl on Polish territory occurred on 24 February 1978 and equalled $59.7^{\circ} \mathrm{C}$. On that day in Suwałki (north-eastern edge of Poland), UTCl reached $-47.1^{\circ} \mathrm{C}\left(\mathrm{Ta}-8.6^{\circ} \mathrm{C}\right.$, wind speed at $10 \mathrm{~m}$ height $14 \mathrm{~m} \cdot \mathrm{s}^{-1}$ ) while

Table 3. Mean yearly average (dUTClavg), minimum (dUTCImin) and maximum (dUTClmax), and highest (dUTCImax abs) yearly UTCl contrasts $\left({ }^{\circ} \mathrm{C}\right)$ between stations located in individual areas, 1951-2018

\begin{tabular}{|l|r|c|c|c|c|}
\hline \multirow{2}{*}{\multicolumn{1}{|c|}{ Area }} & \multicolumn{3}{|c|}{ Mean dUTCl } & \multicolumn{2}{c|}{$\begin{array}{c}\text { Highest dUTCI } \\
\text { and date of occurrence }\end{array}$} \\
\cline { 2 - 6 } & avg & $\min$ & $\max$ & max abs & date \\
\hline PL - Poland & 21.1 & 7.5 & 45.6 & 59.7 & 24.02 .1978 \\
A - Coastal & 8.9 & 0.4 & 30.2 & 41.1 & 30.04 .1985 \\
B - Lakeland & 5.1 & 0.0 & 22.5 & 30.8 & 17.01 .1955 \\
C - North-eastern & 7.3 & 0.3 & 24.2 & 36.9 & 02.03 .1957 \\
D - Central & 13.4 & 2.7 & 33.8 & 50.1 & 14.02 .1979 \\
E - Eastern & 5.8 & 0.2 & 21.9 & 31.3 & 17.01 .1955 \\
F - Sudetic & 5.3 & 0.0 & 29.1 & 43.9 & 11.12 .1952 \\
G - Carpathian & 5.7 & 0.0 & 29.0 & 42.1 & 11.01 .1967 \\
H - Summits & 12.6 & 0.0 & 48.8 & 58.8 & 20.02 .1965 \\
\hline
\end{tabular}


in Wrocław, located $530 \mathrm{~km}$ to the south-west, UTCl was $12.6^{\circ} \mathrm{C}\left(\mathrm{Ta} 7.8^{\circ} \mathrm{C}\right.$ and wind speed $\left.1 \mathrm{~m} \cdot \mathrm{s}^{-1}\right)$. In the largest, Central region (D), the greatest spatial contrast in the 68-year study period also occurred in February: on 14 February 1979 in Płock UTCl was $-42.5^{\circ} \mathrm{C}$, while $300 \mathrm{~km}$ to the south, in Tarnów, UTCl was $7.6^{\circ} \mathrm{C}($ Tab. 3).

\section{Time changes of UTCI contrasts within bioclimatic areas}

Spatial contrasts in UTCl vary distinctly throughout the year, with a summer minimum and a maximum in the months FebruaryMarch (Fig. 4). This primarily reflects the general variability of the weather and its stimulating qualities, which are the greatest at the end of winter and start of spring, and the smallest in July and August. In the Central region, which on average has the greatest contrasts, dUTClavg was around $10.5^{\circ} \mathrm{C}$ in summer and $16.3^{\circ} \mathrm{C}$ in February, while on the coast it varied from $6.8^{\circ} \mathrm{C}$ in August to around $10.5^{\circ} \mathrm{C}$ from February to April, and in the Eastern region (E) it was $4.6^{\circ} \mathrm{C}$ in August and only $7.1^{\circ} \mathrm{C}$ in February. Monthly means of dUTCImax showed higher variation, but also in this case the Lakeland (B) and Eastern (E) regions were distinctly more homogenous in terms of thermal stress. dUTCImin clearly primarily showed high thermal variation in Central region, the biggest and the most differentiated one. Small contrasts in Lakeland region are probably caused by two reasons: small distance between the stations and their insufficient number in the analysis, but mainly due to location on the west part of Poland and lowland topography which facilitates the flow of air masses. A similar mechanism applies to Eastern region, mainly upland but quite plain, where usually the air mass and meteorological conditions in a given day not differ significantly.

As described earlier the UTCl values increased in the analysed 68 years, however their daily inter-station contrasts (dUTCl) decreased. Maximum contrasts decreased particularly distinctly, and as a result so did
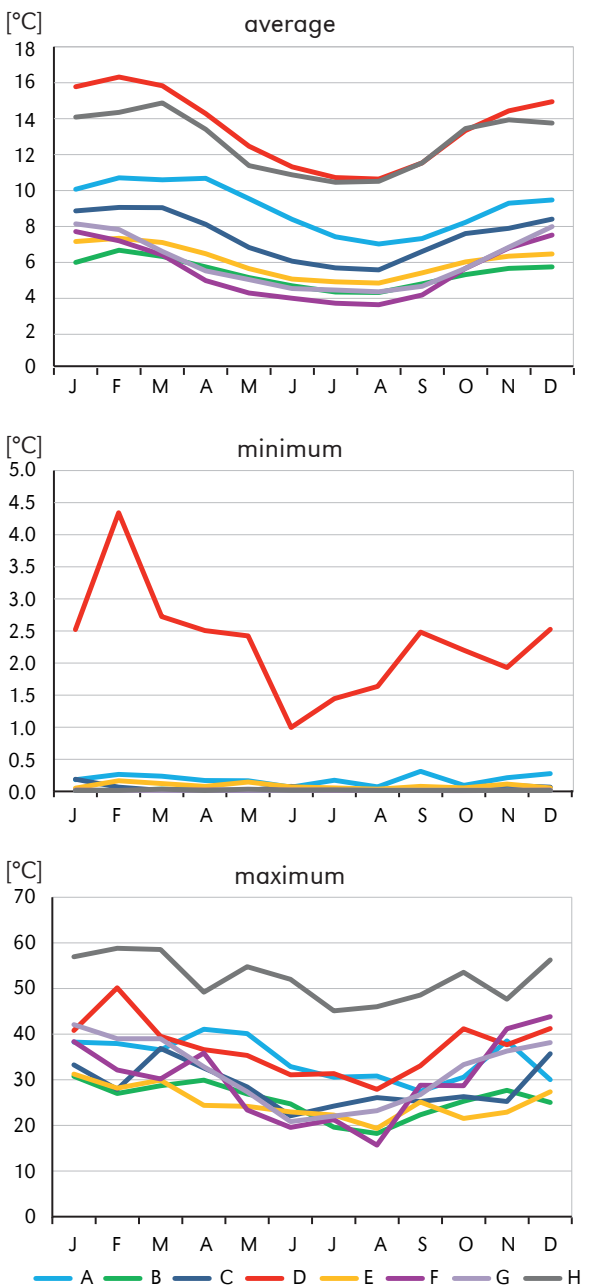

Figure 4. Annual course of average (dUTClavg), maximum (dUTCImax) and minimum (dUTCImin) spatial contrasts in individual areas, 1951-2018

the mean contrasts. However, the lowest values of recorded UTCl contrasts decreased slightly(Fig. 5). dUTClavg for Poland as a whole dropped from $22.9^{\circ} \mathrm{C}$ in 1951 to $19.3^{\circ} \mathrm{C}$ in 2018 (i.e., by $0.54^{\circ} \mathrm{C} / 10$ years). dUTCImax increased by even $1.03^{\circ} \mathrm{C} / 10$ years, while dUTCImin, by $0.18^{\circ} \mathrm{C} / 10$ years. All the decreases were statistically significant at $p \leq 0.05$ (Tab. 4).

Multiannual changes in $\mathrm{dUTCl}$ and their 10-year moving averages show that the period with the most "positive" divergence 

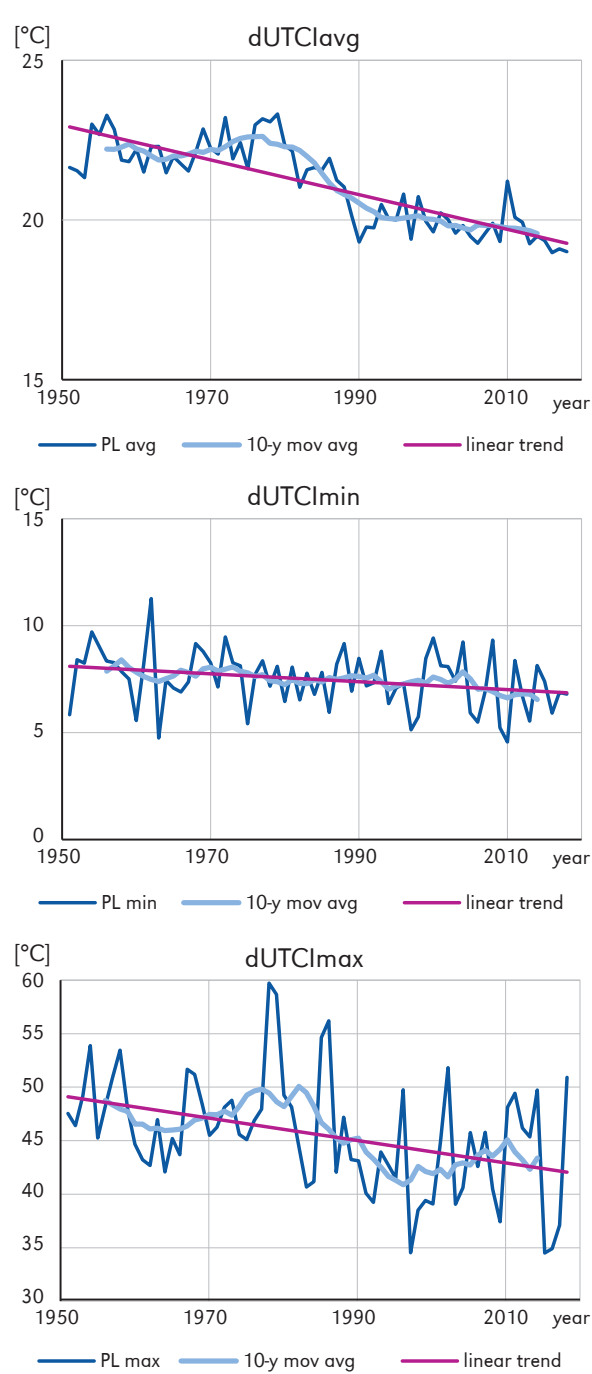

Figure 5. Multiannual changes in mean (dUTClavg), minimum (dUTCImin) and maximum (dUTCImax) yearly contrasts for Poland as a whole with trend and 10-year moving averages (10-y mov avg), 1951-2018

from the trend line was the years 1972-1986. This signifies high spatial variability of the weather in those years in the area of Poland, as different parts of the country were influenced by differing weather conditions. dUTCl reached a maximum of $59.7^{\circ} \mathrm{C}$ in 1978 , and $56.2^{\circ} \mathrm{C}$ in 1986 (Fig. 5). In the same period, distinctly lower dUTCl values were also recorded (Fig. 3). Apart from a general decrease in dUTCl in the analysed 68-year period, after 2005 the 10-year moving average line can be seen to approach the trend line, which indicates a decrease in UTCI differentiation in the area of Poland.

Table 4. 10-year trends $\left({ }^{\circ} \mathrm{C}\right)$ in mean yearly average (dUTClavg), minimum (dUTCImin) and maximum (dUTCImax) UTCl contrasts between stations located in individual areas, 19512018 (bolded values are statistically significant at $p \leq 0.05)$

\begin{tabular}{|l|r|r|r|}
\hline \multicolumn{1}{|c|}{ Area } & Avg & Min & Max \\
\hline PL - Poland & -0.54 & -0.18 & -1.03 \\
A - Coastal & $\mathbf{0 . 1 4}$ & 0.02 & 0.02 \\
B - Lakeland & -0.16 & 0.00 & -0.95 \\
C - North-eastern & -0.32 & -0.02 & -1.04 \\
D - Central & -0.32 & -0.05 & -0.98 \\
E - Eastern & -0.14 & 0.01 & -0.94 \\
F - Sudetic & -0.17 & 0.00 & -0.50 \\
G - Carpathian & $-\mathbf{0 . 3 0}$ & 0.00 & $-\mathbf{1 . 7 5}$ \\
H - Summits & $-\mathbf{0 . 2 4}$ & 0.00 & $-\mathbf{0 . 8 2}$ \\
\hline
\end{tabular}

Figure 6 presents mean annual values of contrasts (dUTClavg) in regions in consecutive years. The scales on the $Y$ axes differ, but on all the charts the range is $10^{\circ} \mathrm{C}$, it has to be done otherwise the charts would be unreadable. Thus in addition to the change trend given in Table 4, also the slope of the trend lines may be compared. In the analysed period, in all regions apart from the Coastal area a decrease in UTClavg variability within regions was observed. The fall in stimuli varies from $-0.16^{\circ} \mathrm{C} / 10$ years in the Lakeland region to $-0.32^{\circ} \mathrm{C} / 10$ years in the centre and north-east of Poland. In the analysed 68 years the greatest changes in stimuli in the distinguished regions occurred in the north-east region, particularly in the years 1968-1993, where also the 10-year moving average curve is distinctly above the trend line. After 1998 thermal stimuli in this region decreased significantly.

The Coastal region differs significantly from the others: dUTCl increased and the average stimuli in the region increased slightly but statistically significantly, by $-0.14^{\circ} \mathrm{C} / 10$ years. 

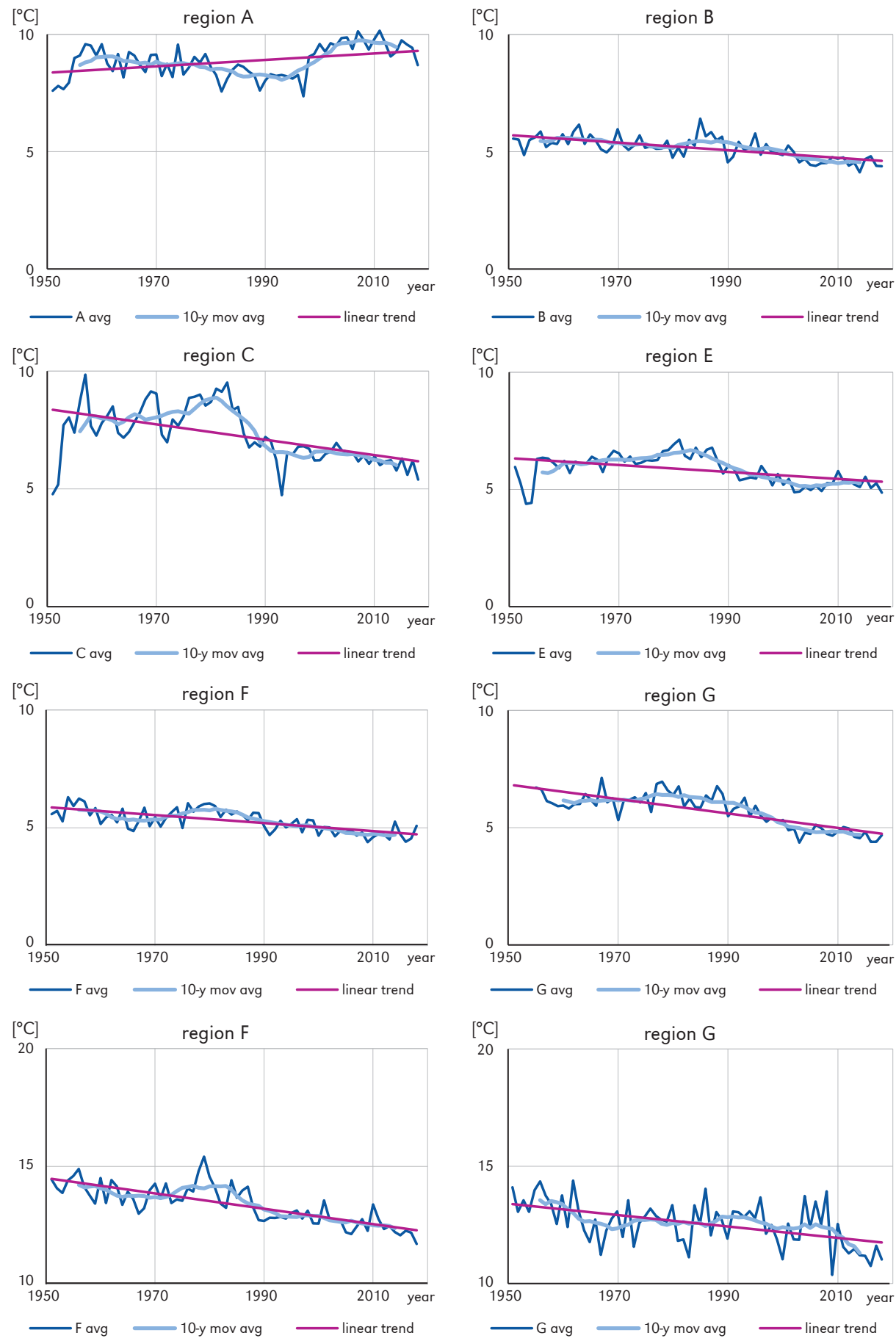

Figure 6. Multiannual changes in mean yearly contrasts (dUTClavg) between stations located in individual regions with trend and 10-year moving averages (10-y mov avg), 1951-2018 

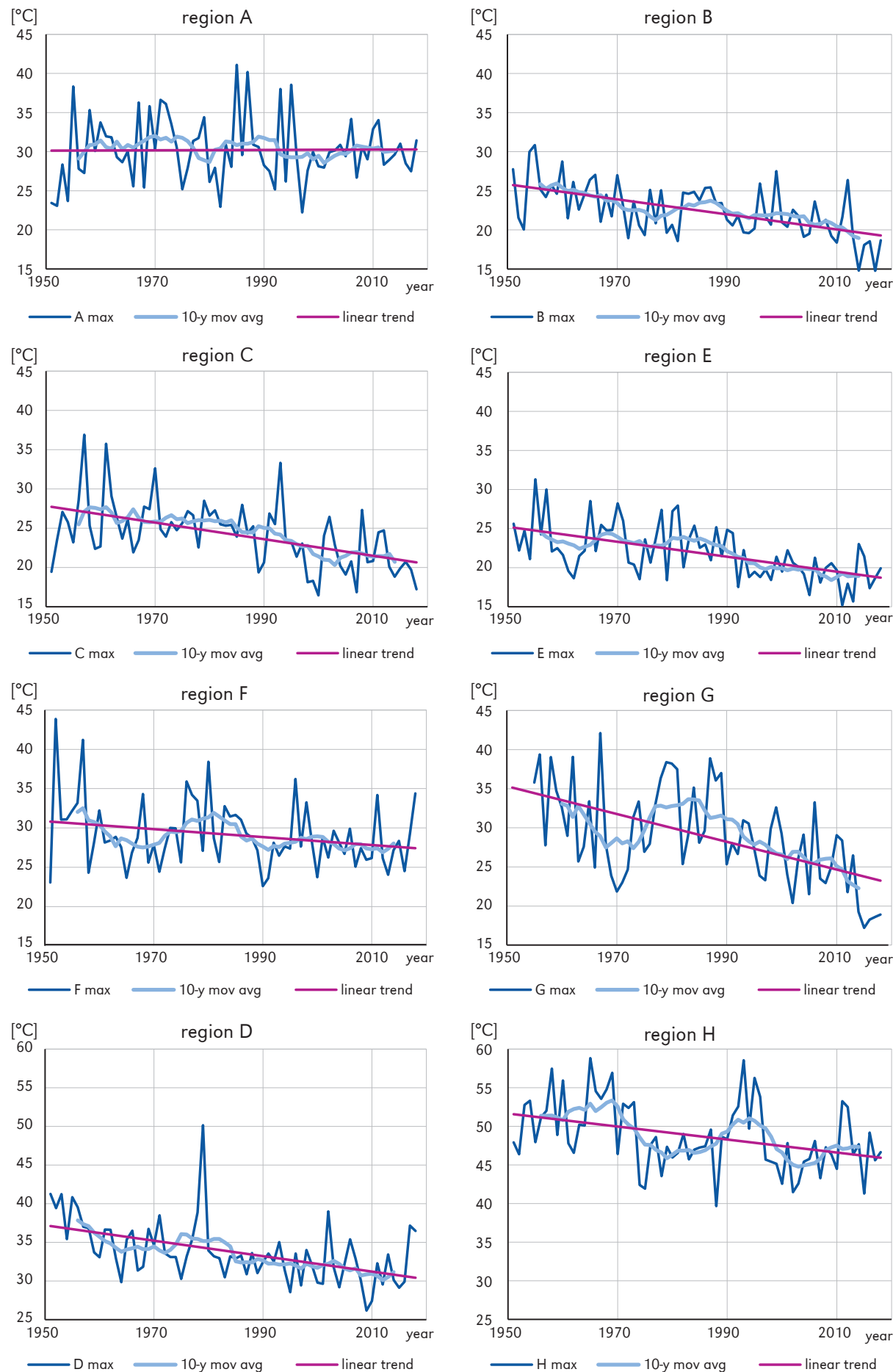

Figure 7. Multiannual changes in maximum yearly contrasts (dUTCImax) between stations located in individual regions with trend and 10-year moving averages (10-y mov avg), 1951-2018 
The increase in dUTCImin and dUTCImax was negligible and statistically insignificant. A distinctive feature of this region is significant differences in stimuli in successive years (Tab. 4, Fig. 6, 7).

Maximum contrasts in UTCl in regions clearly show greater variability than the averages, but also a distinct, sometimes several times higher decrease over the 68 years studied. The greatest decrease in UTCImax in a region occurred in the Carpathians, where it reached $-1.75^{\circ} \mathrm{C} / 10$ years. This means that the dUTCl of a given day between Zakopane and Lesko decreased significantly. This results also from the fact that for the Carpathian region the period under study is 4 years shorter, and in the years 1951-54 the differences in UTCI in most regions were lower compared to the second half of the 1950s. Another clear fall in dUTCImax, by $-1.04^{\circ} \mathrm{C} / 10$ years, occurred in the coolest, north-eastern region (C), in which also the greatest increase in UTCI values was recorded. Thus the region warmed significantly, but also became more thermally homogenous.

The smallest dUTCI decrease was observed in the Sudetic region, which generally had some of the lowest dUTCI. In the regions with the greatest variation in UTCI values, D and $\mathrm{H}$, the downward trend of spatial contrasts was average (Fig. 7).

While on the scale of the whole country the dUTCImin trend is negative, and though small it is statistically significant, no significant changes were noted in any of the regions. In each year there were days when thermal stress was the same in the whole region, and spatial contrasts of UTCI were close to 0 .

\section{Discussion}

To remind, the whole paper is based on UTCI from 12:00 UTC and its different characteristics: daily lowest (UTCImin) and highest (UTCImax) values at all the stations in the area, the spatial averages (UTClavg) and most of all on the daily UTCI spatial contrasts $(\mathrm{dUTCl})$ in each of the areas, defined as the difference between the daily highest and lowest UTCl values in given area.

The significantly higher increase in UTCImin $\left(0.75^{\circ} \mathrm{C} / 10\right.$ years for the whole of Poland) as compared to UTClavg $\left(0.44^{\circ} \mathrm{C} / 10\right.$ years $)$ or UTCImax $\left(0.28^{\circ} \mathrm{C} / 10\right.$ years $)$ confirms the greater upward trend for minimum air temperature than for maximum temperature, observed in Poland in many studies (e.g. Wibig \& Głowicki, 2002; Michalska, 2011). A different analysis shows a greater increase in average January temperature, and a smaller increase in July (Lorenc, 2000), which indirectly reflects the same phenomenon, i.e., a greater increase in the lowest temperature compared to the highest temperature recorded in a given period. The same phenomenon is also visible in the characteristic days analysis, where the decreasing trend of ice or frosty days is much higher than the increasing trend of hot days (Bielec-Bqkowska \& Piotrowicz, 2013; Twardosz \& KossowskaCezak, 2013; Kuchcik, 2017).

The decrease of UTCI values during 1970s and 1980s strictly refers to reduction in surface shortwave radiation and sunshine duration ("global dimming") and a subsequent increase up to the 2000s ("global brightening") observed in Poland and other parts of Europe (e.g. Matuszko, 2014; Sanchez-Lorenzo et al., 2015). 1980 had record-low values of insolation at many stations in Poland (Koźmiński \& Michalska, 2005). The longterm variability in insolation is most often explained by air circulation driven changes in cloudiness (e.g. Houghton et al., 2001; Stjern et al., 2009) or changes in aerosol content in the air (e.g. Wild et al., 2005; Vetter \& Wechsung, 2015).

An analysis of UTCl value and spatial contrasts trends in regions shows some variation and a differing magnitude of changes, and in one case even a different direction of changes. The greatest increase in UTCl, whether average, minimum or maximum, occurred in the coolest, North-eastern region of Poland, where UTClavg increased by $0.73^{\circ} \mathrm{C} / 10$ years. Meanwhile, the smallest increase in UTCl was present 
on Mountain summits, but also on the Baltic Sea coast, i.e., in the north and south of Poland. In an analysis of UTCl trends in the years 1975-2014 in the largest Polish cities, the highest and statistically significant fall in the number of cold stress days (with $\mathrm{UTCl}<-13.0^{\circ} \mathrm{C}$ ) and rise in heat stress days $\left(\mathrm{UTCl}>32.0^{\circ} \mathrm{C}\right.$ ) was also noted in northeastern Poland (Kuchcik, 2017). Long-term analysis of UTCI (1966-2015) in the whole area of Poland showed very similar results, i.e., an increase in days with $\mathrm{UTCl}>32^{\circ} \mathrm{C}$ by 1.3 days $/ 10$ years in north-eastern Poland (Suwałki) and by 2.0 days/10 years in the south (Rzeszów, close to Tarnów), and almost no increase or a very small increase of up to 0.6 days $/ 10$ years on the coast (Tomczyk \& Owczarek, 2020). These results run counter to an analysis of mean area air temperature trends in Poland in the period 1951-2000, according to which the rapidest warming is occurring on the coast and in the Lakeland region (Wójcik \& Miętus, 2014). This demonstrates that UTCl is a significantly different characteristic of the thermal environment than air temperature by itself. Apart from temperature, its value is affected also by solar radiation, wind speed and air humidity.

Błażejczyk et al. (2015) analysed the average number of heat and cold stress days in Poland in the years 1966-2012 on the basis of data from a similar set of stations, but did not calculate regional spatial averages or monthly trends. However, the course of the yearly number of cold and heat stress days was obviously similar to that obtained in the present research.

UTCl variation in regions is distinctly the lowest in summer and highest in February and March. The period from November to March, and February in particular, have the highest frequency of large day-to-day changes in air pressure $(>8.1 \mathrm{hPa})$, and thus the greatest variability in weather and weather differences even between towns that are close together (Koźmiński \& Michalska, 2012; Kuchcik et al., 2013; Bilik et al., 2014; Rozbicka \& Rozbicki, 2016).
In the case of UTCl, the most important stimulus is the index value itself but the stimulus could be also its spatial and day-to-day variability. This is why a decrease in spatial contrasts of UTCl in regions could indicate a decrease in their stimuli. Because the lack of the papers to which these results could be compared with, the Authors try to compare them to another characteristic of weather condition stimuli, i.e., day-to-day air temperature changes, which according the old biometeorological criterion is assumed emperature of $6^{\circ} \mathrm{C}$ is an acute stimulus that influences humans (Bajbakova et al., 1963). The number of such changes in Poland is decreasing significantly: on average in Poland in the years 1985-2014 by 1.1 days/10 years (Kuchcik, 2017), and in the cool half of the year in Kraków over the long period 1901-2010, by 4.9 days/100 years (Matuszko \& Piotrowicz, 2012).

Clear increase of UTCl extreme values and a decrease in UTCl spatial contrasts within regions confirm proven persistence of largescale circulation regimes over Europe (Kyselý, 2008) and whole northern hemisphere (Francis et al., 2020) noted since the mid-1980s and connected probably with Arctic fast warming. The greater persistence of large-scale weather systems results in more frequent heatwaves, cold spells, droughts, flooding, snowfalls, and of course in more frequent extreme high and low values of air temperature and hence UTCI values.

According to UTCl thermally most homogeneous is Lakeland and Eastern regions. Probably because the spatial contrasts are already small here their yearly average decreasing trends are also the smallest in Poland.

Spatial averages of UTCl values in the Carpathian Region are growing faster compared to the Sudetic region and a significantly greater downward trend in dUTCl, including an over threefold greater decrease in dUTCImax, may be observed there. And here is the same problem as mentioned above, no papers to compare the results with. This is anywise reflected in the 
abovementioned paper by Wójcik and Miętus (2014), who like the authors of the present paper analysed mean area temperature in Poland in the years 1951-2010, and pointed out that warming is the fastest in the northern part of the country and the Carpathians, and the slowest in upland areas and the Sudetes. But it should be remembered that UTCl is based not only on air temperature but also on wind speed, cloudiness and humidity. All these variables changed in the 20th century (Błażejczyk \& Twardosz, 2010) and this can affect changes in UTCI. Meanwhile, in the work of Błażejczyk (2019), who analysed air temperature trends in 4 stations in a similar period, 1951-2015, trends in the Sudetes were slightly higher than in the Carpathians, namely $0.40 / 10$ years in Jelenia Góra and 0.27/10 years in Zakopane for mean air temperature. Similarly, the upward trend for average UTCl in the years 19512018 in Jelenia Góra was slightly higher $\left(0.36^{\circ} \mathrm{C} / 10\right.$ years $)$ than the trend for Zakopane $\left(0.30^{\circ} \mathrm{C} / 10\right.$ years $)$. However, taking into account other stations and calculating area averages, the average upward trend for UTCI is greater in the Carpathians than in the Sudetes. Much depends on the selection and number of stations under analysis.

\section{Conclusions}

One of the most interesting results of the paper is its documentation of a significant decrease in thermal stress in north-eastern Poland, particularly visible in the increase in UTCImin. It was even twice as high there as in other regions of the country. The country's coolest region is clearly warming and becoming more homogeneous in terms of thermal stress.

While a significant increase in the value of UTCI was observed in all regions of Poland over the years 1951-2018, the contrasts of thermal stress both in Poland as a whole and in individual regions showed the opposite trend - they decreased significantly. It is probably due to growing persistence of large-scale weather systems and indicates a decrease in contrasts of weather conditions within the regions, but also in all of Poland.

The greatest thermal contrasts, and also the greatest contrasts in perceived conditions, occur when different parts of Poland are influenced by different pressure systems and air masses. The fact that these contrasts are clearly diminishing may indicate the decline of the "transitional" quality of the Polish climate.

Furthermore, the high dUTCl in the central region means that in further analyses of thermal stress, taking into account a greater number of stations, this region should be divided, at least by separating its southern part. This requires further research that would take into account more meteorological stations in this region.

Editors' note:

Unless otherwise stated, the sources of tables and figures are the authors', on the basis of their own research.

\section{References}

Bajbakova, E.M., Nevraev, G.A., Čubukov, L.A. (1963). Metodika analiza klimata kurortov i meteorologičeskich uslovij klimatoterapii. In Očerki po klimatologii kurortov (pp. 5-42). Moscow: Nauka.

Bielec-Bąkowska, Z., Piotrowicz, K. (2013). Temperatury ekstremalne w Polsce w latach 1951-2006. Prace Geograficzne, 132, 59-98. https://doi.org/10.4467/20833113PG.13.004.1094

Bilik, A., Gawęda, B., Gluza, A., Siwek, K. (2014). Przebieg ciśnienia atmosferycznego w Lublinie w latach 1951-2010. Annales Universitatis Maria Curie-Skłodowska Lublin - Polonia, Sectio B, 69(2), 133-142. 
Błażejczyk, A., Błażejczyk, K., Baranowski, J., Kuchcik, M. (2018). Heat stress mortality and desired responses of healthcare system in Poland. International Journal of Biometeorology, 62(3), 307-318. https://doi.org/10.1007/s00484-017-1423-0

Błażejczyk, K. (2004). Bioklimatyczne uwarunkowania rekreacji i turystyki w Polsce. Prace Geograficzne IGiPZ PAN, 192, Warsaw: IGiPZ PAN.

Błażejczyk, K. (2019). Sezonowa i wieloletnia zmienność niektórych elementów klimatu w Tatrach i Karkonoszach w latach 1951-2015. Przeglad Geograficzny, 91(1), 41-62. https://doi.org/10.7163/PrzG.2019.1.2

Błażejczyk, K., Baranowski, J., Błażejczyk, A. (2015). Wpływ klimatu na stan zdrowia w Polsce: stan aktualny oraz prognoza do 2100 roku. Warsaw: Wyd. Akademickie SEDNO.

Błażejczyk, K., Epstein, Y., Jendritzky, G., Staiger, H., Tinz, B. (2012). Comparison of UTCl to selected thermal indices. International Journal of Biometeorology, 56(3), 515-535. https://doi.org/10.1007/s00484-011-0453-2

Błażejczyk, K., Kuchcik, M., Błażejczyk, A., Milewski, P., Szmyd, J. (2014). Assessment of urban thermal stress by UTCl - experimental and modeling studies: an example from Poland. Die Erde, 144(1-2), 105-116. https://doi.org/10.12854/erde-145-3

Błażejczyk, K., Kunert, A. (2011). Bioklimatyczne uwarunkowania rekreacji i turystyki w Polsce (2nd ed.). Monografie, 13, Warsaw: IGiPZ PAN.

Błażejczyk, K., Twardosz, R. (2010). Long-term changes of bioclimatic conditions in Cracow (Poland). In R. Przybylak, R. Majorowicz, J. Brázdil, M. Kejna (Eds.), The Polish climate in the European context: An historical overview (pp. 235-246). Springer, Science+Business Media B.V. https://doi.org/10.1007/978-90-481-3167-9_10

Bröde, P., Fiala, D., Błażejczyk, K., Holmér, I., Jendritzky, G., Kampmann, B., Tinz, B., Havenith, G. (2012). Deriving the operational procedure for the Universal Thermal Climate Index (UTCI). International Journal of Biometeorology, 56(3), 481-494. https://doi.org/10.1007/s00484-011-0454-1

Bröde, P., Błażejczyk, K., Fiala, D., Havenith, G., Holmér, I., Jendritzky, G., Kuklane, K., Kampmann, B. (2013). The Universal Thermal Climate Index UTCl compared to ergonomics standards for assessing the thermal environment. Industrial Health, 51(1), 16-24. https://doi.org/10.2486/indhealth.2012-0098

Burkart, K., Meier, F., Schneider, A., Breitner, S., Canário, P., Alcoforado, M.J., Scherer, D., Endlicher, W. (2016). Modification of heat-related mortality in an elderly urban population by vegetation (Urban Green) and proximity to water (Urban Blue): evidence from Lisbon, Portugal. Environmental Health Perspectives, 124(7), 927-934. https://doi.org/10.1289/ehp.1409529

Cheshire, W.P. (2016). Thermoregulatory disorders and illness related to heat and cold stress. Autonomic Neuroscience: Basic and Clinical, 196, 91-104. https://doi.org/10.1016/j.autneu.2016.01.001

Cheung, C.S.C., Hart, M.A. (2014). Climate change and thermal comfort in Hong Kong. International Journal of Biometeorology, 58(9), 137-148. https://doi.org/10.1007/s00484-012-0608-9

De Freitas, C.R., Grigorieva, A.E. (2017). A comparison and appraisal of a comprehensive range of human thermal climate indices. International Journal of Biometeorology, 61(3), 487-512. https://doi.org/10.1007/s00484-016-1228-6

di Napoli, C., Barnard, Ch., Prudhomme, Ch., Cloke, H.L., Pappenberger, F. (2020). ERA5-HEAT: A global gridded historical dataset of human thermal comfort indices from climate reanalysis. Geoscience Data Journal. https://doi.org/10.1002/gdj3.102

Dobek, M., Wereski, S., Krzyżewska, A. (2020). Bioclimatic conditions of Lublin based on the Universal Thermal Climate Index (UTCI). Miscellanea Geographica, 24(3), 118-127. https://doi.org/10.2478/mgrsd-2020-0025

Epstein, Y., Moran, D.S. (2006). Thermal comfort and heat stress indices. Industrial Health, 44(3), 388-398. https://doi.org/10.2486/indhealth.44.388 
Francis, J.A., Skific, N., Vavrus, S.J. (2020). Increased persistence of large-scale circulation regimes over Asia in the era of amplified Arctic warming, past and future. Scientific Reports, 10:14953. https://doi.org/10.1038/s41598-020-71945-4

Gasparrini, A., Guo, Y., Hashizume, M., Lavigne, E., Zanobetti, A., Schwartz, J., Tobias, A., Tong, S., Rocklöv, J., Forsberg, B., Leone, M., de Sario, M., Bell, M.L., Guo, Y-L.L., Wu, C-f., Kan, H., Yi, S-M., Coelho, M.S.Z.S., Saldiva, P.H.N., ... Armstrong, B. (2015). Mortality risk attributable to high and low ambient temperature: A multicountry observational study. Lancet 386(9991), 369-375.

https://doi.org/10.1016/S0140-6736(14)62114-0

Gumiński, R. (1948). Próba wydzielenia dzielnic rolniczo-klimatycznych w Polsce. Przeglad Meteorologiczny i Hydrologiczny, 1(1), 7-20.

Heim, R.R. Jr. (2015). An overview of weather and climate extremes - products and trends. Weather and Climate Extremes, 10, 1-9. https://doi.org/10.1016/j.wace.2015.11.001

Houghton, J.T., Ding, Y., Griggs, D.J., Noguer, M., van der Linden, P.J., Dai, X., Maskell, K., Johnson, C.A. (Eds.) (2001). Climate Change 2001: The Scientific Basis. Cambridge: Cambridge University Press.

IPCC. (2013). Summary for Policymakers. In T.F. Stocker, D. Qin, G.K. Plattner, M. Tignor, S.K. Allen, J. Boschung, A. Nauels, Y. Xia, V. Bex, P.M. Midgley (Eds.), Climate Change 2013: The Physical Science Basis. Contribution of Working Group I to the Fifth Assessment Report of the Intergovernmental Panel on Climate Change. Cambridge: Cambridge University Press. https://www.ipcc.ch/site/assets/uploads/2018/02/WG1AR5_SPM_FINAL.pdf

IPCC. (2018). Global Warming of $1.5^{\circ} \mathrm{C}$. An IPCC Special Report on the impacts of global warming of $1.5^{\circ} \mathrm{C}$ above pre-industrial levels and related global greenhouse gas emission pathways, in the context of strengthening the global response to the threat of climate change, sustainable development, and efforts to eradicate poverty. https://www.ipcc.ch/site/assets/uploads/sites/2/2019/06/SR15_Full_Report_High_Res.pdf

Jendritzky, G., de Dear, R., Havenith, G. (2012). UTCI - Why another thermal index? International Journal of Biometeorology, 56(3), 421-428. https://doi.org/10.1007/s00484-011-0513-7

Kenney, W.L. (1985). A review of comparative responses of men and women to heat stress. Environmental Research, 37(1), 1-11. https://doi.org/10.1016/0013-9351(85)90044-1

Köppe, C., Kovats, S., Jendritzky, G., Menne, B. (2004). Heat-waves: Risks and responses. Health and Global Environmental Change Series, No. 2. Copenhagen, Denmark: WHO.

Kozłowska-Szczęsna, T. (1991). Antropoklimat Polski - próba syntezy. Zeszyty IGiPZ PAN, 1, Warsaw: IGiPZ PAN.

Kozłowska-Szczęsna, T., Błażejczyk, K., Krawczyk, B., Limanówka, D. (2002). Bioklimat uzdrowisk polskich i możliwości jego wykorzystania w lecznictwie. Monografie, 3, Warsaw: IGiPZ PAN.

Koźmiński, C., Michalska, B. (2005). Usłonecznienie w Polsce. Szczecin: Akademia Rolnicza w Szczecinie, Uniwersytet Szczeciński.

Koźmiński, C., Michalska, B. (2012). Międzydobowe zmiany ciśnienia atmosferycznego w Polsce niekorzystne dla organizmu człowieka. Przegląd Geograficzny, 84(3), 361-374. https://doi.org/10.7163/przg.2012.3.1

Krawczyk, B. (1993). Typologia i ocena bioklimatu Polski na podstawie bilansu cieplnego ciała człowieka. Prace Geograficzne IGiPZ PAN, 160. Wrocław, Warsaw, Kraków: Wydawnictwo Polskiej Akademii Nauk.

Kuchcik, M. (2017). Zmiany warunków termicznych w Polsce na przełomie XX i XXI wieku i ich wpływ na umieralność. Prace Geograficzne, 263, Warsaw: IGiPZ PAN.

Kuchcik, M. (2020). Mortality and thermal environment (UTCI) in Poland - long-term, multi-city study. International Journal of Biometeorology. https://doi.org/10.1007/s00484-020-01995-w

Kuchcik, M., Błażejczyk, K., Szmyd, J., Milewski, P., Błażejczyk, A., Baranowski, J. (2013). Potencjał leczniczy klimatu Polski. Warsaw: Wydawnictwo Akademickie SEDNO. 
Kyselý, J. (2008). Influence of the persistence of circulation patterns on warm and cold temperature anomalies in Europe: Analysis over the 20th century. Global and Planetary Change, 62(1-2), 147-163. https://doi.org/10.1016/j.gloplacha.2008.01.003

Lewis, S.C., King, A.D. (2017). Evolution of mean, variance and extremes in 21 st century temperatures. Weather and Climate Extremes, 15, 1-10. https://doi.org/10.1016/j.wace.2016.11.002

Lorenc, H. (2000). Studia nad 220-letnia (1779-1998) seriq temperatury powietrza w Warszawie oraz ocena jej wiekowych tendencji. Materiały Badawcze IMGW, Seria Meteorologia, 31. Warsaw: IMGW.

Matuszko, D., Piotrowicz, K. (2012). Wieloletnia zmienność sytuacji meteorotropowych w Krakowie. Przeglad Geograficzny, 84(3), 413-422. https://doi.org/10.7163/PrzG.2012.3.5

Michalska, B. (2011). Tendencje zmian temperatury powietrza w Polsce. Prace i Studia Geograficzne, 47, 67-76.

Nastos, P.T., Matzarakis, A. (2012). The effect of air temperature and human thermal indices on mortality in Athens, Greece. Theoretical and Applied Climatology, 108(3-4), 591-599. https://doi.org/10.1007/s00704-011-0555-0

National Academies of Sciences, Engineering, and Medicine. (2016). Attribution of extreme weather events in the context of climate change. Washington, DC: The National Academies Press. https://doi.org/10.17226/21852

Okołowicz, W., Martyn, D. (1979). Regiony klimatyczne Polski. In Atlas Geograficzny Polski. Warsaw: PPWK.

Okoniewska, M., Więcław, M. (2013). Zmienność wieloletnia warunków bioklimatycznych w II połowie XX wieku w Polsce w godzinach okołopołudniowych na podstawie uniwersalnego wskaźnika obciążenia cieplnego. Journal of Health Sciences Czasopismo Naukowe, 3(15), 116-129.

Owczarek, M. (2019). The influence of large-scale factors on the heat load on human beings in Poland in the summer months. Theoretical and Applied Climatology, 137(1-2), 855-869. https://doi.org/10.1007/s00704-018-2633-z

Parsons, K.C. (2014). Human thermal environments: The effects of hot, moderate, and cold environments on human health, comfort, and performance (3rd ed.). London - New York: Taylor \& Francis. https://doi.org/10.1201/b16750

Paszyński, J., Krawczyk, B. (1970). Climatic regions of Poland. Idójaras, 74(1-2), 124-128.

Piotrowicz, K. (2007). Temperatura powietrza. In D. Matuszko (Ed.). Klimat Krakowa w XX wieku (pp. 99-112). Kraków: IGiGP UJ.

Romer, E. (1949). Regiony klimatyczne Polski. Prace Wrocławskiego Towarzystwa Naukowego, 16. Seria B. Wrocław: Wrocławskie Towarzystwo Naukowe.

Rozbicka, K., Rozbicki, T. (2016). Zależność bodźcowości ciśnienia od cyrkulacji atmosferycznej w Warszawie. Acta Scientarium Polonorum Formatio Circumiectus, 15(3), 121-136. https://doi.org/10.15576/ASP.FC/2016.15.3.121

Sanchez-Lorenzo, A., Wild, M., Brunetti, M., Guijarro, J.A., Hakuba, M.Z., Calbó, J., Mystakidis, S., Bartok, B. (2015). Reassessment and update of long-term trends in downward surface shortwave radiation over Europe (1939-2012). Journal of Geophysical Research: Atmospheres, 120(18), 9555-9569. https://doi.org/10.1002/2015JD023321

Schmuck, A. (1965). Regiony pluwiotermiczne w Polsce. Czasopismo Geograficzne, 36(3), 239-244.

Stjern, C.W., Kristjansson, J.E., Hansen, A.W. (2009). Global dimming and global brightening - an analysis of surface radiation and cloud cover data in northern Europe. International Journal of Climatology, 29(5), 643-653. https://doi.org/10.1002/joc.1735

Tomczyk, A.M., Owczarek, M. (2020). Occurrence of strong and very strong heat stress in Poland and its circulation conditions. Theoretical and Applied Climatology, 139(3-4), 893-905.

https://doi.org/10.1007/s00704-019-02998-3 
Twardosz, R., Kossowska-Cezak, U. (2013). Exceptionally hot summers in Central and Eastern Europe (1951-2010). Theoretical and Applied Climatology, 112(3-4), 617-628.

https://doi.org/10.1007/s00704-012-0757-0

Urban, A., Kyselý, J. (2014). Comparison of UTCI with other thermal indices in the assessment of heat and cold effects on cardiovascular mortality in the Czech Republic. International Journal of Environmental Research and Public Health, 11(1), 952-967. https://doi.org/10.3390/ijerph110100952

Vetter, T., Wechsung, T. (2015). Direct aerosol effects during periods of solar dimming and brightening hidden in the regression residuals: Evidence from Potsdam measurements. Journal of Geophysical Research: Atmospheres, 120(21), 11299-11305. https://doi.org/10.1002/2015JD023669

Wibig, J., Głowicki, B. (2002). Trends of minimum and maximum temperature in Poland. Climate Research, 20(2), 123-133. https://doi.org/10.3354/cr020123

Wibig, J., Podstawczyńska, A., Rzepa, M., Piotrowski, P. (2009a). Coldwaves in Poland - frequency, trends and relations with atmospheric circulation. Geographia Polonica, 82(1), 47-59.

https://doi.org/10.7163/GPOL.2009.1.4

Wibig, J., Podstawczyńska, A., Rzepa, M., Piotrowski, P. (2009b). Heatwaves in Poland - frequency, trends and relations with atmospheric circulation. Geographia Polonica, 82(1), 33-46. https://doi.org/10.7163/GPOL.2009.1.3

Wild, M., Gilgen, H., Roesch, A., Ohmura, A., Long, C.L., Dutton, E.G., Forgan, B., Kallis, A., Russak, V., Tsvetkov, A. (2005). From dimming to brightening: Decadal changes in solar radiation at Earth's surface. Science, 308(5723), 847-850. https://doi.org/10.1126/science.1103215

World Meteorological Organization (WMO). (1999). Weather, climate and health. Geneva, Switzerland: WMO.

Woś, A. (1993). Klimat Polski. Warsaw: PWN.

Wójcik, R., Miętus, M. (2014). Niektóre cechy wieloletniej zmienności temperatury powietrza w Polsce (1951-2010). Przeglad Geograficzny, 86(3), 339-364. https://doi.org/10.7163/PrzG.2014.3.3

Wu, F., Yang, X., Shen, Z. (2019). Regional and seasonal variations of outdoor thermal comfort in China from 1966 to 2016. Science of The Total Environment, 665, 1003-1016. https://doi.org/10.1016/j.scitotenv.2019.02.190

Ziernicka-Wojtaszek, A., Zawora, T. (2008). Zróżnicowanie pluwiotermiczne Polski w świetle współczesnych zmian klimatu. Acta Agrophysica, 12(1), 289-297.

Zeng, D., Wu, J., Mu, Y., Deng, M., Wei, Y., Sun, W. (2020). Spatial-temporal pattern changes of UTCI in the China-Pakistan Economic Corridor in recent 40 years. Atmosphere, 11, 858, https://doi.org/10.3390/atmos11080858 